\title{
DETEKSI KESEGARAN IKAN TONGKOL (Euthynnus Affinis) SECARA OTOMATIS BERDASARKAN CITRA MATA MENGGUNAKAN BINARY SIMILARITY
}

\author{
Hurriyatul Fitriyah*1, Dahnial Syauqy², Faizal Andy Susilo ${ }^{3}$ \\ 1,2,3 Teknik Komputer, Jurusan Teknik Informatika, Fakultas Ilmu Komputer, Universitas Brawijaya \\ Email: ${ }^{1}$ hfitriyah@.ac.id, ${ }^{2}$ dahnial87@ub.ac.id, ${ }^{3}$ faizalandysusilo.507@gmail.com \\ *Penulis Korespondensi
}

(Naskah masuk: 04 Agustus 2020, diterima untuk diterbitkan: 05 Oktober 2020)

\begin{abstract}
Abstrak
Ikan tongkol (Euthynnus Affinis) adalah salah satu ikan yang paling banyak diminati di Indonesia karena kandungan proteinnya hampir setara ikan tuna, namun dengan harga relatif lebih murah. Ikan termasuk komoditi pangan yang mudah rusak tanpa adanya penanganan khusus ketika ikan ditangkap. Padahal, mutu dan nilai jual ikan sangat tergantung dari parameter kesegaran ikan itu sendiri. Penelitian ini mengembangkan metode deteksi kesegaran ikan tongkol menggunakan fitur berupa citra mata ikan. Mata ikan dapat digunakan untuk mengetahui tingkat kesegarannya. Ikan segar memiliki pupil bulat berwarna hitam yang utuh dan jernih di tengahnya. Hal tersebut kemudian dijadikan knowledge-based dari proses deteksi kesegaran ikan. Sebelum dilakukan proses deteksi, dilakukan proses pre-processing untuk mendapatkan gambar kepala ikan secara otomatis. Selanjutnya dilakukan perhitungan similarity antara citra biner kepala ikan dengan 2 buah template, yakni Template-Mata untuk mendeteksi mata dan Template-Tengah untuk mendeteksi bulat hitam di tengah mata. Sebanyak 30 citra mata ikan dengan kriteria segar dan tidak segar digunakan sebagai data pengujian. Dari pengujian, kedua template tersebut mampu membedakan ciri morfologis dari mata ikan yang segar dengan tepat.
\end{abstract}

Kata kunci: ikan tongkol, kesegaran, pengolahan citra, citra mata, binary similarity

\section{AUTOMATIC DETECTION OF TONGKOL FISH (Euthynnus affinis) FRESHNESS LEVEL BASED ON EYE IMAGE USING BINARY SIMILARITY}

\begin{abstract}
Tongkol fish (Euthynnus Affinis) is one of the most popular fish in Indonesia because it has more protein than tuna, but with a relatively cheaper price. Fish is a perishable food commodities if it is caught without any special handling. In fact, the quality and value of fish selling depends on the parameters of the freshness of the fish itself. This study developed a method for detecting freshness of tongkol fish using features that is extracted from the image of a fish's eye. Fish eye can be used to determine the level of freshness. Fresh fish have whole round and clear black pupils in the middle. This is then made into knowledge-base on the process of detecting the freshness. First, this fully automatic detection performed a pre-processing process to obtain automatic fish head images. It was then compared with two templates, which are eye-template and middle-template. If the fish head image has similarity below certain threshold then it is classified as fresh fish, or else it is non-fresh fish. A total of 30 images of fish with fresh and non-fresh criteria were used as test data. From the test, the two templates can classify the morphological characteristics of fresh fish eyes precisely.
\end{abstract}

Keywords: tongkol fish, freshness, image processing, fish eye image, binary similarity

\section{PENDAHULUAN}

Berdasarkan data, potensi produksi hasil kelautan di Indonesia termasuk cukup besar dimana menempati posisi 13 besar di dunia (Ronny, 2011). Hal ini terkait kondisi geografis Indonesia yang merupakan negara dengan sekitar 17 ribu pulau dengan garis pantai lebih dari 104 ribu $\mathrm{km}$ (Kementrian Kelautan dan Perikanan, 2014). Berdasarkan statistik, produksi perikanan tangkap di laut menunjukkan tren yang makin meningkat. Pada tahun 2015 produksi perikanan tangkap sejumlah 6,2 juta ton meningkat menjadi 6,3 juta ton pada tahun 2016 (Ditjen Perikanan Tangkap, 2017). 
Terdapat berbagai jenis ikan dengan nilai ekonomi yang cukup tinggi dalam wilayah perairan Indonesia, antara lain tongkol, tenggiri, cakalang, tuna kakap serta beberapa jenis biota laut lain (Adisanjaya, 2010). Namun, salah satu jenis ikan yang paling banyak diminati dengan alasan harga yang terjangkau namun kadar proteinnya hampir setara ikan tuna adalah ikan tongkol (Euthynnus Affinis), yakni sekitar 26,2 g/100 g (Milo, dkk., 2011).

Selain untuk konsumsi dalam negeri, hasil produksi perikanan tangkap kelautan tersebut juga untuk diekspor ke negara lain. Mengingat bahwa ikan termasuk komoditas pangan yang mudah rusak, maka terkadang perlu penanganan khusus pada ikan yang baru ditangkap. Salah satu bentuk penanganan tersebut misalnya adalah dengan pengawetan pada ikan segar sebelum dipasarkan (Susianawati, dkk., 2007). Hal tersebut dilakukan karena pada ikan yang mati akan mengalami perubahan kimiawi dan adanya aktivitas mikroorganisme. Dengan demikian, biasanya nelayan menurunkan suhu pada ikan dengan memberikan es dengan tujuan untuk mencegah bakteri pembusuk masuk ke dalam ikan (Sidiki, dkk, 2015).

Penanganan khusus yang dilakukan pada ikan segar bertujuan untuk menjaga kesegaran ikan karena mutu produk perikanan pada umumnya dinilai dari aspek kesegarannya. Demikian pentingnya untuk mendeteksi kesegaran ikan, sehingga proses pengolahan serta nilai jual ikan sangat tergantung karenanya (Murniyati \& Sunarman, 2000).

Untuk dapat mendeteksi kesegaran ikan, terdapat beberapa metode yang dapat dilakukan. Salah satu metode yang dapat digunakan adalah dengan menggunakan analisis kimiawi atau biokimiawi ikan. Cara lain adalah dengan menggunakan analisis kandungan mikrobiologi pada ikan (Ozogul, 2010). Namun metode-metode yang umumnya dilakukan tersebut kurang efisien dari segi biaya dan waktu yang secara tidak langsung sangat berkaitan dengan kapasitas produksi ikan (Indrabayu, 2016).

Dengan alasan tersebut, banyak metode-metode baru yang dikembangkan dengan basis sistem instrumentasi dan penggunaan perangkat komputasi elektronik. Pada tahun 2014, Gu dkk melakukan penelitian tentang deteksi kesegaran ikan. Fitur data yang digunakan adalah data statistik dari iris mata ikan, yang dikombinasikan dengan fitur tekstur permukaan kulit ikan. Hasil kombinasi vektor dari fitur tersebut digunakan untuk mendeteksi kesegaran ikan. Hasil dari pengujian penelitian tersebut menunjukkan akurasi deteksi sebesar 86.3\% (Gu, $\mathrm{dkk}$, 2014). Pada penelitian lain, Indrabayu melakukan deteksi kesegaran ikan banding menggunakan parameter nilai RGB dari citra bandeng sebagai referensi dan citra uji menggunakan persamaan Euclidean dengan threshold tertentu. Hasil implementasi metode tersebut menunjukkan rata-rata akurasi yang dihasilkan dalam mendeteksi kesegaran bandeng adalah sekitar 90\% (Indrabayu, dkk, 2016).

Berdasarkan permasalahan yang telah dijabarkan, maka dalam penelitian ini akan diusulkan metode untuk mendeteksi kesegaran ikan tongkol menggunakan citra mata ikan. Selanjutnya, pemaparan paper penelitian ini dibagi menjadi beberapa bab, yakni bab metodologi yang membahas mengenai detail mekanisme penelitian, bab pembahasan dan hasil yang membahas mengenai hasil pengujian terhadap metodologi yang telah dilakukan, serta bab kesimpulan yang menyampaikan poin-poin penting yang didapatkan selama proses penelitian.

\section{METODE PENELITIAN}

Tingkat kesegaran ikan sangat berkorelasi dengan kondisi mata dan insang ikan tersebut (Jarmin, dkk, 2012). Ikan yang segar akan menunjukkan kondisi mata yang cerah, kornea jernih dan pupil hitam (Iswari, dkk, 2017). Fitur visual tersebut sangat sesuai dengan implementasi kamera yang digunakan sebagai sensor.

Dalam penelitian ini telah diambil 30 citra yang terdiri dari 12 ikan segar dan 18 tidak segar. Kesegaran yang menjadi label dari setiap ikan tersebut diberikan oleh pakar. Ikan tersebut diambil secara langsung dari pabrik pengepul ikan tongkol. Setiap citra diambil dalam kotak tertutup yang didesain agar tidak ada cahaya luar yang menyinari ikan. Lampu yang digunakan dalam kotak tersebut merupakan lampu putih standar. Pengaturan tersebut berguna agar nilai RGB yang didapatkan adalah berasal kondisi pencahayaan yang sama. Jarak ikan ke kamera adalah $30 \mathrm{~cm}$. Kamera yang digunakan adalah kamera standar dimana setiap gambar yang diambil memiliki ukuran 320x240 pixel. Gambar 1 menunjukkan contoh citra ikan segar dan tidak segar yang didapatkan dalam pengambilan data.

Untuk dapat mendeteksi kesegaran ikan tongkol berdasarkan citra, dibutuhkan beberapa tahapan preprocessing. Tahapan ini dibutuhkan sebab Template Matching citra dilakukan pada gambar biner.

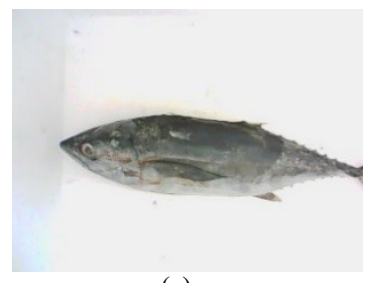

(a)

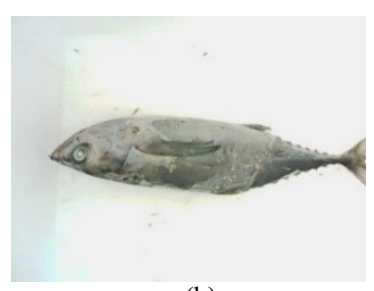

(b)
Gambar 1. Citra Ikan Tongkol; (a) Segar, (b) Tidak Segar

\subsection{Pre-processing}

Pre-processing merupakan tahapan yang diperlukan untuk menyiapkan gambar sebelum diumpankan ke algoritma. Dalam penelitian ini tahapan tersebut didesain untuk mendapatkan citra biner dari kepala ikan secara otomatis. Proses 
cropping kepala ikan secara otomatis memungkinkan pengembangan alat sistem deteksi kesegaran ikan yang sederhana dan tanpa inputan manual dari manusia.

Pre-processing yang telah dilakukan terdiri dari 4 tahap, yakni: (1) Konversi RGB ke grayscale, (2) Segmentasi, (3) Filtering, (4) Cropping kepala ikan.

\section{a. Konversi RGB ke Grayscale}

Konversi ini dilakukan agar foreground ikan dapat dipisahkan dari background alas kotak putih. Pemilihan warna putih dilakukan agar mempermudah proses segmentasi dimana ikan tongkol sebagai object of interest memiliki perpaduan warna keabuan, metalik dan hitam. Konversi tersebut menggunakan metode Luma yang umum digunakan yakni pada Persamaan (1). I $(x, y)$ merupakan intensitas keabuan pada posisi pixel $(x, y)$.

$I(x, y)=0.2989 R+0.5870 G+0.1140 B$

b. $\quad$ Segmentasi Menggunakan Otsu's Thresholding Segmentasi dilakukan guna mendapat citra ikan tongkol saja. Sementasi yang dilakukan dalam penelitian ini mengunakan metode Otsu's Thresholding yang umum digunakan karena menggunakan konsep class-variance. Otsu's thresholding mencari pixel threshold yang memberikan within-class variace paling kecil dan between-class variance paling besar. Metode tersebut juga bersifat adaptif sesuai dengan intensitas masingmasing gambar. Otsu's Threshoding menghasilkan gambar biner dimana pixel ikan akan diberi nilai 1 dan pixel non-ikan diberi nilai 0 dengan mengacu pada nilai threshold yang dihitung menggunakan
Persamaan (2). Pixel ikan memiliki nilai intensitas lebih kecil daripada pixel background.

$$
I_{B}=\left\{\begin{array}{l}
1, I_{G}(x, y) \leq \text { threshold } \\
0, I_{G}(x, y)>\text { threshold }
\end{array}\right.
$$

\section{c. $\quad$ Filtering}

Citra biner hasil segmentasi umumnya masih belum menghasilkan pemisahan pixel yang tepat antara foreground dengan background. Filter umumnya diterapkan pada citra biner hasil segmentasi untuk menghilangkan false-positive dan false-negative pada gambar biner tersebut. Dalam penelitian ini, citra biner ikan terlihat memiliki noise berjenis salt-and-pepper, sehingga metode filtering yang diterapkan adalah Median Filter. Filter tersebut mengambil median dari tetangga $7 \times 7$. Nilai ketetanggaan tersebut ditetapkan secara manual. Filter tersebut dipilih karena hasil pemfilteran hanya akan menghilangkan noise tanpa merubah bentuk biner ikan.

\section{d. Cropping Kepala Ikan}

Untuk mempermudah dan mempercepat proses Template Matching dalam mencari mata ikan, maka dilakukan cropping berdasarkan koordinat. Cropping tersebut akan memperkecil jumlah pixel saat pencarian. Kepala ikan umumnya berada di 1/7 bagian depan dari ikan. Sehingga jika citra biner ikan memiliki ukuran $60 \times 210$ maka hasil cropping berukuran $60 \times 30$.

Keempat poses pre-processing tersebut ditunjukkan pada Gambar 2. Hasil pada gambar tersebut adalah untuk citra pada Gambar 1(a).

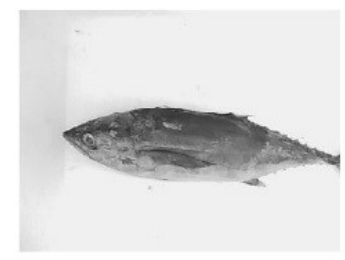

(a)

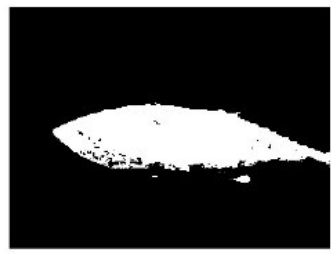

(b)

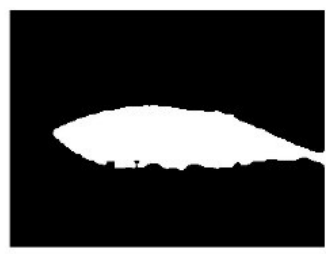

(c)

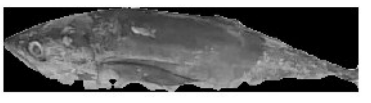

(d)

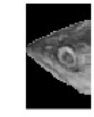

(e)

Gambar 2. Tahapan Pre-processing; (a) citra Grayscale, (b) citra biner hasil Thresholding, (c) hasil Filtering, (d) citra hasil Filtering, (e) citra hasil Cropping

\subsection{Deteksi Mata Ikan Segar menggunakan Binary Similarity}

Seperti terlihat pada Gambar 1(a), mata ikan segar terlihat bulat utuh dan memiliki pupil tegas berwarna hitam bulat dibanding citra ikan tidak segar pada Gambar 1(b). Untuk mendeteksi mata ikan yang segar dapat dilakukan klasifikasi berdasarkan fitur intensitas seperti profil histogram dari citra grayscale.
Namun implementasi metode tersebut pada ikan tongkol kurang berhasil sebab warna ikan tongkol hanya berupa gradasi citra keabuan dan kulitnya cenderung berkilau metalik. Kulit yang berkilau tersebut dapat memiliki intensitas yang lebih tinggi daripada mata ikan itu sendiri. Dalam pencarian mata ikan segar secara otomatis dalam citra hasil cropping kepala ikan, jika terdapat ikan tidak segar namun 
kulitnya mengkilat, maka dapat terdeteksi sebagai ikan segar.

Penelitian ini menggunakan alternatif lain dalam mencari mata ikan segar yakni menggunakan nilai similarity antara citra biner ikan dengan template mata ikan segar. Sebelum melakukan perhitungan similarity, maka dibutuhkan proses konversi hasil cropping kepala ikan dari citra grayscale menjadi citra biner.

\section{a. Konversi Grayscale ke Biner}

Untuk mendapatkan citra biner dari hasil cropping kepala ikan yang masih dalam warna citra grayscale, maka dilakukan proses thresholding terlebih dahulu. Nilai batas yang digunakan tidak dicari secara otomatis seperti menggunakan Otsu's Thresholding, namun menggunakan batas yang dipilih secara manual. Berdasarkan pengamatan visual dari mata ikan segar, nilai hitam berkisar di antara nilai 50-100 dari skala nilai grayscale $0-255$ ( 8 bit). Sehinnga pixel yang memiliki nilai dalam rentang tersebut akan diberi harga 0 dan sebaliknya diberi harga 1. Gambar 3 menunjukkan citra biner hasil thresholding dari gambar cropping kepala ikan di Gambar 2(e).

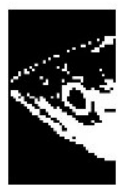

Gambar 3. Citra biner kepala ikan

\section{b. Perhitungan Similarity}

Terdapat banyak ragam persamaan similarity dari nilai biner. Penelitian ini menggunakan persamaan similarity sederhana yakni Rand similarity (atau Sokal-Michener's simple matching) dengan menggunakan Persamaan (3). TP adalah TruePositive sedangkan TN adalah True Negative dimana dalam tabel contingency merupakan komponen diagonal yang berisi kesesuaian antara nilai pixel citra biner dengan template. Sedangkan $F P$ dan $F N$ adalah False-Positive dan False-Negative yang berisi ketidaksesuaian antara nilai pixel yang dicocokkan. Semakin besar nilai similarity menunjukkan kecocokan yang semakin besar antara citra biner dengan template.

$$
\text { Rand Similarity }=\frac{T P+T N}{T P+F P+F N+T N}
$$

\section{c. Template-Mata}

Dapat dilihat pada Gambar 1 bahwa mata ikan segar terdiri dari bentuk bulat hitam di tengah, yang dilingkari oleh bulatan putih dan bulatan hitam lagi pada sisi terluarnya. Dari gambar yang telah diambil, didapati bahwa mata ikan rata-rata berukuran $15 \times$ 15 piksel. Ukuran tersebut kemudian dipakai sebagai ukuran template mata ikan segar Template biner mata ikan segar dalam penelitian ini dibuat berdasarkan ciri visual mata ikan segar. Gambar 4(a) dan 4(b) adalah contoh beberapa mata ikan segar dalam warna biner. Umumnya, gambar-gambar biner mata ikan terseut digunakan sebagai template pada metode template matching. Namun, mata ikan-ikan segar tersebut tidak digunakan sebagai template dalam penelitian ini mengingat bentuknya yang sangat beragam. Meski secara umum berbentuk bulat, namun setiap mata ikan memiliki bentuk yang agak pipih di satu atau dua sisi.

Sehingga penelitian ini menggunakan Template-Mata berukuran kecil yakni $15 \times 15$ pixel yang dibuat dengan bentuk bulat yang standar untuk mengatasi beragam bentuk mata ikan segar (Gambar 4(c)). Perbandingan citra dalam warna biner dilakukan mengingat nilai intensitas ikan dapat beragam, namun memiliki bentuk morfologinya yang serupa.

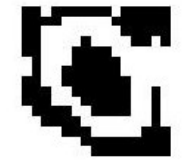

(a)

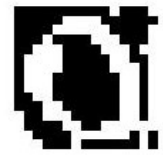

(b)

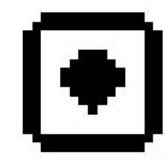

(c)
Gambar 4. Citra biner;

(a) dan (b) mata ikan segar, (c) Template-Mata

\section{d. Template-Tengah}

Perbedaan ikan segar dan tidak segar seperti terlihat pada Gambar 1 hanya pada titik putih tengah di pupil pada ikan tidak segar yang berukuran sangat kecil jika dibandingkan dengan ukuran window. Sehingga setelah dihitung nilai similarity terhadap template pertama, diperlukan template kedua yang khusus mendeteksi apakah di bagian tengah mata ikan bernilai hitam penuh atau tidak.

Template-Tengah yang digunakan berukuran sangat kecil yakni $3 \times 3$ piksel dengan nilai 0 atau hitam semua. Template-Tengah tersebut dibandingkan dengan pixel di bagian tengah dari window kandidat mata ikan segar.

\section{e. Algoritma Binary Similarity untuk Identifikasi Kesegaran Ikan}

Algoritma deteksi kesegaran ikan pertama-tama membuat window pada kepala ikan yang sudah tercrop secara otomatis. Window tersebut bergeser pada setiap pixel. Sehingga jika ukuran hasil cropping kepala ikan adalah $60 \times 30$ pixel, maka terdapat $(60-15) \times(30-15)=45 \times 15=675$ window yang akan dievaluasi atau dibandingkan dengan template mata ikan segar (template-Mata). Setiap window kemudian dibandingkan dengan TemplateMata dan dihitung nilai similarity-nya menggunakan Rand Similairty. Jika nilai similarity terbesar dari window tersebut kurang dari sebuah nilai batas tertentu, maka dianggap tidak ada mata ikan yang terdeteksi. Namun jika nilai similarity diatas nilai batas yang ditetapkan, maka window dimana terdapat 
mata ikan di dalamnya tersebut akan dievaluasi kesegarannya. Nilai batas tersebut dinamai dengan batas-mata.

Selanjutnya window tersebut dievaluasi menggunakan template kedua yakni TemplateTengah. Jika didapati Rand Similarity dari kandidat tersebut lebih besar dari batas maka ikan tersebut dianggap sebagai ikan segar. Dan sebaliknya jika Rand Similarity dari kandidat tersebut kurang dari nilai batas yang ditentukan, maka ikan dianggap sebagai tidak segar. Nilai batas tersebut dinamakan dengan batas-tengah. Diagram alir dari algoritma deteksi kesegaran ikan menggunakan binary similarity diperlihatkan pada Gambar 5.

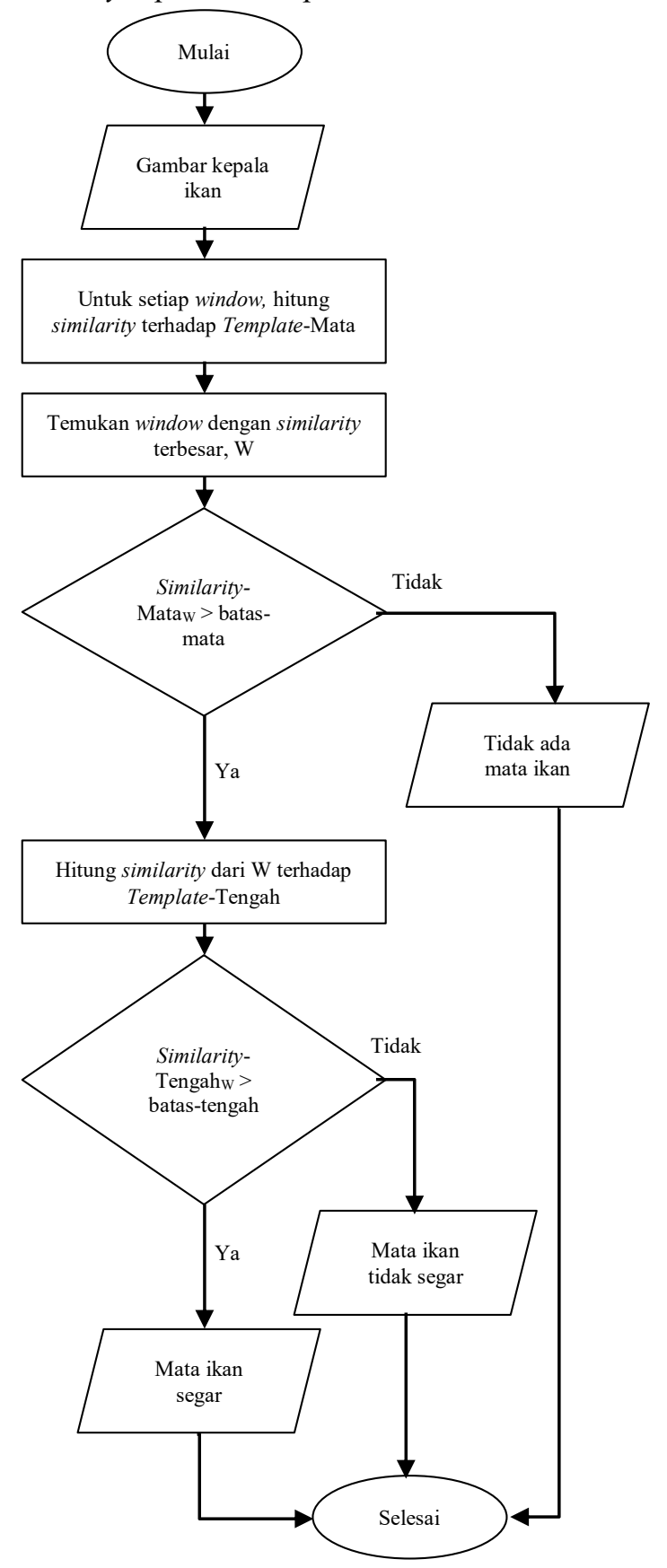

Gambar 5. Diagram Alir Algoritma

\section{HASIL DAN PEMBAHASAN}

Pengujian dilakukan untuk menemukan batasmata dan batas-tengah guna menentukan kesegaran ikan berdasarkan pola matanya.

\section{a. Pengujian Batas-Mata}

Nilai batas-mata ditentukan dengan menguji di setiap kelipatan 10 (10\%-100\%). Dari hasil pengujian terhadap gambar kepala ikan, didapati batas $60 \%$ yang memiliki akurasi deteksi mata ikan tertinggi. Pengecekan akurasi deteksi mata ikan dilakukan secara visual. Batas $60 \%$ tersebut setara dengan kecocokan sebesar 136 dari total 225 pixel yang dibandingkan. Nilai maksimum similarity dari citra ikan yang kurang dari batas $60 \%$ tersebut maka dianggap tidak terdapat mata ikan yang terdeteksi.

Nilai similarity di bawah $60 \%$ umumnya terdapat pada ikan dengan posisi kepala terlalu miring dibandingkan dengan badannya seperti gambar 6 (a). Nilai dibawah batas-mata tersebut juga terdapat pada ikan dengan kondisi yang sangat buruk sehingga tidak terdapat bulatan tengah hitam sama sekali 6(b). Gambar 6(a) merupakan contoh nilai similarity sebesar 133 yang disebabkan posisi mata ikan yang miring dibandingkan dengan baddan ikan. Sedangkan Gambar 6(b) merupakan contoh nilai similarity sebesar 135 .

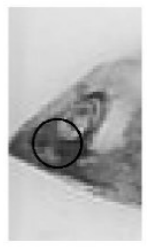

(a)

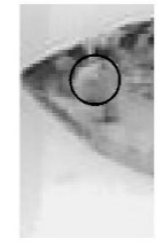

(b)
Gambar 6. Citra grayscale dengan nilai similarity kurang dari $60 \%$; (a) kondisi mata ikan miring,

(b) mata ikan sangat tidak segar

Gambar 7 menunjukkan nilai batas $60 \%$ mampu mendeteksi mata ikan baik untuk mata ikan segar (gambar 7(a) dan mata ikan tidak segar (gambar 7.b). Template-Mata yang menggunakan morfologi bentuk bulat hitam di tengah memungkinkan pendeteksian mata secara invariant. Hal ini memungkinkan pendeteksian mata dilakukan baik pada posisi ikan menghadap ke atas atau ke bawah seperti terlihat pada beragam posisi hadap ikan di Gambar 7. Meski demikian letak kepala ikan harus diletakkan di sebalah kiri dari arah kamera. Hal ini karena proses cropping dilakukan dari ujung sebelah kiri dari ikan.

\section{b. Pengujian Batas-Tengah}

Nilai batas-tengah ditentukan dengan menguji di setiap kelipatan 1 antara 1-9 dimana jumlah pixel yang dibandingkan adalah $3 \times 3$ piksel. Hasil pengujian berdasarkan pengamatan visual menunjukkan bahwa nilai batas-tengah untuk 
membedakan mata ikan segar atau tidak segar adalah sebesar 9 piksel atau bulat penuh.

\section{c. Analisa penggunaan Binary Similarity dengan Dua Template}

Pemberian batas $60 \%$ pada batas-mata belum dapat mendeteksi ikan segar yang memiliki mata hitam bulat utuh di tengah. Hal ini karena perbedaan ikan segar dan tidak segar seperti terlihat pada Gambar 1 hanya pada titik putih tengah pada ikan tidak segar yang berukuran sangat kecil jika dibandingkan dengan ukuran window. Sehingga setelah dihitung nilai similarity terhadap template pertama, diperlukan template kedua yang khusus mendeteksi apakah di bagian tengah mata ikan bernilai hitam penuh atau tidak. Ukuran bulat putih di tengah mata ikan tidak segar yang menjadi pembeda antara mata segar dan tidak adalah relatif kecil, \pm 9 piksel. Ukuran kecil tersebut tidak signifikan dibanding ukuran mata ikan sendiri, \pm 225 piksel. Sehingga ketika kecocokan nilai biner pada pixel bagian luar mata yang tinggi dapat menutupi ketidakcocokan pada lokasi tengah mata.

Gambar 8 menunjukkan perbandingan nilai similarity dari 30 gambar ikan dimana nomor 1-12 adalah ikan segar dan 13-30 adalah ikan tidak segar. Nilai similarity dari Template-Mata antara ikan segar dan tidak segar pada Gambar 8 terlihat serupa. Sehingga Template-Tengah diperlukan dalam metode pendeteksian sebagai pembeda. Dari grafik di Gambar 8 tersebut, diketahui bahwa meski memiliki nilai similarity-mata serupa, namun ikan tidak segar memiliki nilai similarity-tengah yang berbeda dengan ikan segar, yakni lebih kecil.

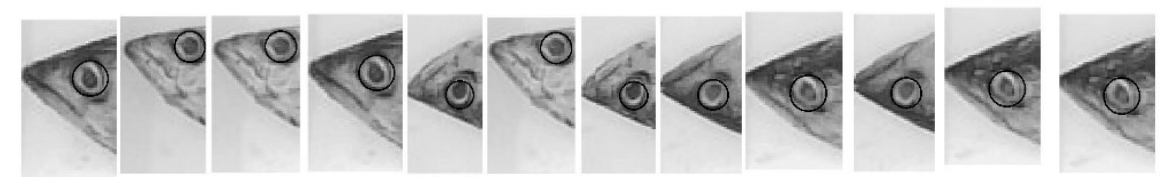

(a)
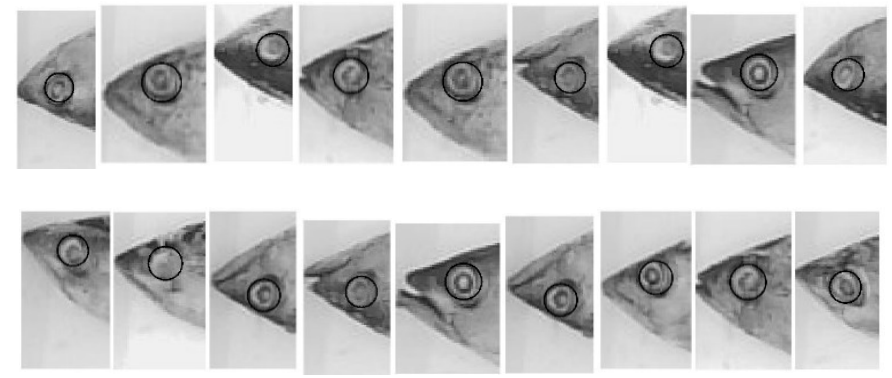

(b)

Gambar 7. Hasil deteksi mata ikan segar menggunakan template-Mata: (a) ikan segar, (b) ikan tidak segar

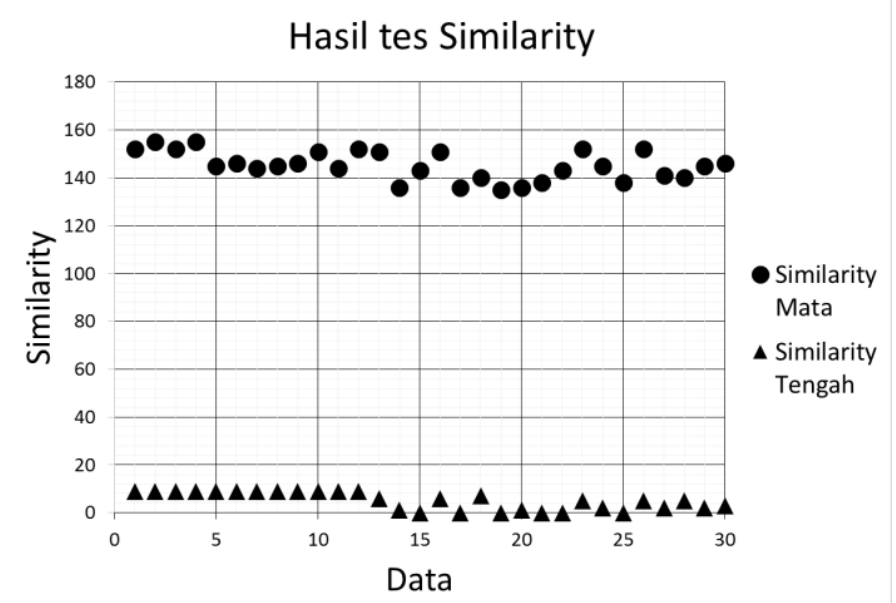

Gambar 8. Hasil nilai similarity dari Template-Mata dan Template-Tengah

\section{KESIMPULAN}

Dalam penelitian ini telah dibuat pendeteksian mata ikan tongkol yang segar menggunakan perhitungan similarity pada citra biner dengan 2 buah template, yakni Template-Mata dan TemplateTengah. Kedua template tersebut mampu membedakan ciri morfologis dari mata ikan yang segar yakni keberadaan pupil bulat hitam utuh di tengah mata yang dikelilingi oleh bulat putih dan kemudian dikelilingi oleh bulat hitam. Pemilihan fitur pembeda berupa ciri morofologis lebih dipilih daripada fitur intensitas pixel pada vektor warna grayscale karena mata ikan dapat memiliki beragam 
tingkat kecerahan. Kulit ikan tongkol dapat memiliki kecerahan lebih tinggi daripada mata ikan sendiri karena adanya sisik berwarna metalik.

Penelitian ini masih mengambil citra ikan tongkol berukuran seragam. Penelitian lanjutan pada ukuran dan kondisi ikan tongkol yang bervariasi perlu dilakukan guna mendapatkan template mata ikan tongkol segar yang lebih adaptif.

\section{DAFTAR PUSTAKA}

ADISANJAYA, N. 2010. Potensi, Produksi Sumber Daya Ikan di Perairan Laut Indonesia dan Permasalahannya. Seminar Potensi Hasil Perikanan Indonesia. Jakarta

DITJEN PERIKANAN TANGKAP. 2018. Produksi Perikanan Tangkap (Ton). [online] Tersedia di http://statistik.kkp.go.id/sidatikdev/2.php? $\mathrm{x}=2$ [diakses pada tanggal $31 \mathrm{Juli}$ 2018 pukul 13:55 WIB]

GU, J., HE, N., WU, X.X. 2014. A New Detection Method for Fish Freshness. Seventh International Symposium on Computational Intelligence and Design.

INDRABAYU, NISWAR, M., AMAN, A. 2016. Sistem Pendeteksi Kesegaran Ikan Bandeng Menggunakan Citra. Jurnal Infotel Vol.8 No.2.

ISWARI, N.M.S, WELLA, RANNY. 2017. Fish Freshness Classification Method based on Fish Image using K-Nearest Neighbor. International Conference On New Media Studies.

JARMIN, R., KHUAN, L.Y., HASHIM, H. AND RAHMAN, N.H.A. 2012. A Comparison on
Fish Freshness Determination Method. International Conference on System Engineering and Technology

KEMENTRIAN KELAUTAN DAN PERIKANAN. 2014. Rancangan Undang-undang Kelautan. Kementrian Kelautan dan Perikanan. Jakarta

MILO, M.S., EKAWATI, L.M, \& PRANATA, F.S. 2011. Mutu Ikan Tongkol (Euthynnus affinis) di Kabupaten Gunungkidul dan Sleman Daerah Istimewa Yogyakarta. Fakultas Teknobiologi Universitas Atma Jaya Yogyakarta.

MURNIATI, A.S \& SUNARMAN. 2000. Pendinginan, Pembekuan, Pengawetan Ikan. Kanisius. Yogyakarta.

OZOGUL, Y. 2010. Methods for freshness quality and deterioration. Di dalam: Nollet LML, Toldra F, editor. Handbook of Seafood and Seafood Products Analysis. USA: Taylor and Francis Group, LLC. Hlm 189-213.

RONNY. 2011. Tingkat Konsumsi Ikan: Peluang, Hambatan dan Strategi. Warta Pasar Ikan, $14,1-2$

SIDIKI, V.T, NAIU, A.S, \& DALI, F.A. 2015. Mutu Organoleptik dan Mikrobiologis Ikan Tongkol yang Diawetkan dengan Bawang Putih Selama Penyimpanan Suhu Ruang. Jurnal Ilmiah Perikanan dan Kelautan. Volume 3, Nomor 3

SUSIANAWATI, R., SYA'RANI, L., \& AGUSTINI, T.W. 2007. Kajian Penerapan GMP dan SSOP pada Produk Ikan Asin Kering dalam Upaya Peningkatan Keamanan Pangan di Kabupaten Kendal. Jurnal Pasir Laut, 2 (2), 40-53. 
Halaman ini sengaja dikosongkan 